Dr DRAGAN BOGETIĆ, naučni savetnik

Institut za savremenu istoriju

Beograd, Trg Nikole Pašića 11

dbogetic@gmail.com

UDK 341.17(4)"1975"

originalan naučni rad

primljeno: 9. mart 2016.

prihvaćeno: 20. april 2016.

\title{
JUGOSLOVENSKI NASTUP NA KONFERENCIJI O EVROPSKOJ BEZBEDNOSTI I SARADNJI U HELSINKIJU 1973-1975.
}

APSTRAKT: U radu su izloženi ključni stavovi Jugoslavije u vezi sa pitanjem evropske bezbednosti i saradnje tokom Konferencije u Helsinkiju, od jula 1973. do avgusta 1975. Zajedno sa grupom evropskih nesvrstanih i neutralnih država, Jugoslavija je u velikoj meri doprinela tome da se ova konferencija oslobodi blokovskih okvira i da se kroz demokratski dijalog svih učesnika pristupi rešavanju najvažnijih međunarodnih problema.

KLJUČNE REČI: blokovi, neutralne i nesvrstane zemlje, SAD, SSSR, Jugoslavija, KEBS, saradnja, granice, osnovne slobode i prava, pregovori, sporazumi

Tokom prve polovine 70-ih godina prošlog veka mogu se pratiti sve energičnija nastojanja Josipa Broza Tita i njegovih saradnika da maksimalno ojačaju evropsku komponentu jugoslovenske politike nesvrstanosti i da u meri u kojoj je to mogućno - suzbiju sve prisutniju tendenciju da nesvrstanost pretežno dobije obeležja afro-azijskog pokreta.

Doduše, politički krugovi u Beogradu su nesumnjivo bili zadovoljni što je na Samitu nesvrstanih u Lusaki, septembra 1970, konačno prihvaćena jugoslovenska inicijativa o potrebi formiranja pokreta koji bi okupljao sve vanblokovske zemlje. Jugoslavija, kao lider tog pokreta, obezbedila je sebi respektabilnu poziciju u sferi međunarodnih odnosa i ulogu značajnog posrednika u pregovorima dveju supersila. Tim pre, što su nesvrstane zemlje

* Rad je deo projekta Srpsko društvo u jugoslovenskoj državi u 20. veku: između demokratije i diktature (177016) koji finansira Ministarstvo prosvete, nauke i tehnološkog razvoja Republike Srbije. 
$\mathrm{u}$ to vreme imale ubedljivu većinu u Ujedinjenim nacijama i s lakoćom obezbeđivale usvajanje čitavog niza odluka i deklaracija u toj organizaciji kompatibilnih sa svojim ključnim spoljnopolitičkim prioritetima. ${ }^{1}$

Ali, višegodišnje utapanje u Treći svet nosilo je opasnost da Jugoslavija u Evropi dobije status svojevrsne „sive zone“ za koju se nije tačno znalo da li pripada taboru socijalističkih država ili ne. Tito je otvoreno iznosio svoje strahovanje o tome da postojeće stanje može dovesti do situacije „da jednog dana visimo u vazduhu“. ${ }^{2}$ Sve više se, naime, činila realnom bojazan da Amerikanci - radi postizanja sovjetskih koncesija oko nekih važnih evropskih i svetskih pitanja - potisnu u drugi plan interese Jugoslavije i odustanu od dotadašnje strategije podržavanja jugoslovenske nezavisnosti. Aktuelna spremnost Sjedinjenih Država da izađu u susret sovjetskoj inicijativi za sazivanje Konferencije o evropskoj bezbednosti na kojoj bi trebalo konačno da se trajno sankcioniše stanje u Evropi uspostavljeno tokom posleratnog razdoblja (posebno nepovredivost postojećih granica) i sklonost dveju supersila da direktnim pregovorima kroje političku kartu sveta, itekako su išli u prilog ovakvim strahovanjima jugoslovenskih zvaničnika. Mada je Tito zagovarao politiku miroljubive koegzistencije među sukobljenim blokovima i podržavao doktrinu američkog predsednika Ričarda Niksona (Richard Nixon) o potrebi da razdoblje konfrontacije ustupi mesto razdoblju pregovora, strahovao je da sve naglašenija uzajamna kooperativnost dveju supersila ne rezultira na kraju njihovim nagodbama na račun malih država. ${ }^{3}$

Osim jugoslovenskih rezervi u pogledu bipolarnog detanta, proizašlih iz strahovanja od američko-sovjetske nagodbe koja bi išla na štetu Jugoslavije, Titu i njegovim saradnicima je smetalo i to što su pripreme za KEBS sve više nagoveštavale suprematiju dveju blokovskih grupacija u razmatranju i regulisanju takoreći svih važnijih međunarodnih pitanja. Ta pitanja bi, po proceni zvaničnog Beograda, bila rešavana sa pozicija sile, međusobno priznatih i uvažavanih interesa, uticajnih sfera koje su počivale na ravnoteži i konsenzusu sile i legitimiteta najmoćnijih. Takav sistem ravnoteže snaga

${ }^{1}$ Dragan Bogetić, „Jugoslavija između Istoka i Zapada“, u: Jugoslavija u Hladnom ratu, Zbornik radova, urednik Aleksandar Životić (Beograd: Institut za noviju istoriju Srbije (INIS), 2010), 13-36.

2 Arhiv Jugoslavije (AJ), CK SKJ, 507, III/151-3, Diskusija J. B. Tita, Petnaesta sednica CK SKJ, 3-4. decembar 1970.

${ }^{3}$ Leo Mates, Međunarodni odnosi socijalističke Jugoslavije (Beograd: BIGZ, 1976); Dragan Bogetić, Jugoslovensko-američki odnosi 1961-1971 (Beograd: Institut za savremenu istoriju (ISI), 2012); Lidija Čehulić Vukadinović, Euroatlantizam i suvremeni međunarodni odnosi (Zagreb: Politička kultura, 2010); J. Maresca, To Helsinki: The Conference on Security and Cooperation in Europe, 1973-1975 (Durham: Berghahn Books, 1985); Radovan Vukadinović, Evropska sigurnost i suradnja (Zagreb: Globus, 1976). 
u svetu bio je u direktnoj koliziji sa konceptom nesvrstavanja, ali i u koliziji sa jugoslovenskim nastojanjima da u rešavanju ključnih međunarodnih problema učestvuju sve države ravnopravno. Iz tog razloga, Tito je stalno kritikovao ograničenost aktuelnog bipolarnog detanta i provizornost rešenja usvojenih od strane dveju supersila mimo ili čak protiv volje ostalih država. Takvo stanje u međunarodnim odnosima u svojoj biti predstavljalo je negaciju Pokreta nesvrstanosti kao važnog i samostalnog međunarodnog faktora. ${ }^{4}$

Stoga su jugoslovenski zvaničnici pridavali veliki značaj pripremama za Konferenciju o evropskoj bezbednosti i saradnji, smatrajući da bi ovaj skup potencijalno mogao odigrati izuzetno važnu ulogu, kako u sklopu reafirmacije osnovnih premisa politike nesvrstanosti, tako i u sklopu nastojanja za maksimalnim jačanjem evropske komponente spoljne politike Jugoslavije. Polazilo se, uz to, i od stava da evropska bezbednost nesumnjivo predstavlja glavnog garanta bezbednosti Jugoslavije. ${ }^{5}$

Tito i njegovi saradnici su bili svesni da realizacija ovih ciljeva nije mogućna bez sinhronizovanog zajedničkog nastupa svih vanblokovskih država učesnika KEBS-a. Stoga je bilo nužno da malobrojna grupa evropskih nesvrstanih država - Jugoslavija, Malta i Kipar ostvari što prisniju saradnju i usaglasi nastup sa evropskim neutralnim državama - Austrijom, Švajcarskom, Finskom i Švedskom. Činilo se da je to sasvim ostvarljivo budući da su obe grupe zemalja imale isti interes: da se onemoguće nastojanja blokovskih grupacija da deluju kao zatvorene političke i vojne celine, usredsređene na postizanje kompromisa koji su se ticali njihovih užih interesa i strateških opredeljenja. U protivnom, u međuprostoru između blokovskih saveza neutralne i nesvrstane države bi imale ulogu statista, koji ne bi ozbiljnije mogli da utiču na tokove konferencije. U takvoj situaciji, vanblokovske evropske države su polazeći od uzajamno povezanih interesa i sličnih stanovišta pristupile usaglašavanju svojih aktivnosti, što je kasnije dovelo do postepenog uobličavanja akcione grupe nesvrstanih i neutralnih država na KEBS-u, koja je dala snažan pečat toku skupa i sadržini usvojenih dokumenata. ${ }^{6}$

${ }^{4}$ Dušan Nikoliš, SAD. Strategija dominacije (Beograd: BIGZ, 1985); Dragan Bogetić, „Američke analize budućnosti Jugoslavije posle Tita s početka 70-tih godina“, Tokovi istorije, br. 1, (2012), 159-174; Ivo Visković, „Odnosi Jugoslavije i Sjedinjenih Američkih Država“, Jugoslovenski pregled, XXXII, br. 1, (1988), 23-45; Ljubodrag Dimić, Jugoslavija i Hladni rat. Ogledi o spoljnoj politici Josipa Broza Tita (1944-1974), (Beograd: Arhipelag, 2014), 357-383.

${ }^{5}$ Diplomatski arhiv Ministarstva spoljnih poslova Republike Srbije (DAMSP), Politička arhiva (PA), Jugoslavija, 1970, fasc. 229, sign. 49410, Jugoslovenski pogledi na probleme evropske saradnje i bezbednosti; Isto, 1972, fasc. 143, sign. 422922, Neka obeležja sadašnje evropske situacije i naši zadaci; AJ, Predsedništvo SFRJ, 803-608, Uoči sveevropske konferencije u Helsinkiju.

6 Ranko Petković, Aktivnost grupe neutralnih i nesvrstanih zemalja na KEBS-u (Zagreb: FPZ, 1979); Thomas Ficher, „The N+N and the Folow-up Meeting in Belgrade 1977/78“, in: From Helsinki to Belgrade, editors Vladimir Bilandžić, Dittmar Dahlmann, Milan Kosanović (Bonn: Bonn University Press, 2012). 
Stavovi i delatnost Jugoslavije na planu evropske bezbednosti i saradnje bili su sastavni deo njenog opšteg prilaza međunarodnim odnosima i proizilazili su iz njenog položaja evropske, nesvrstane i socijalističke zemlje. Generalna strategija Jugoslavije prema Evropi predstavljala je, zapravo, primenu njene politike nesvrstanosti na evropske prilike. Stoga su njeni osnovni stavovi i sadržaji nužno prelazili okvire evropskog kontinenta. Prvi obuhvatniji pogled jugoslovenskih zvaničnika u vezi sa održavanjem Konferencije o evropskoj bezbednosti bio je izložen 25. jula 1969, u njihovom odgovoru na Memorandum finske vlade, koji je u to vreme upućen vladama svih evropskih država, SAD i Kanadi. ${ }^{7}$ Jugoslavija je u pismu finskom premijeru Urhu Kekonenu (Urho Kekkonen) odlučno podržala finsku inicijativu i naglasila spremnost da se „u skladu sa svojom opštom politikom aktivne miroljubive koegzistencije i nesvrstanosti... u punoj meri angažuje u naporima da se uspostavi atmosfera poverenja i razvije široka i svestrana saradnja na bazi principa Povelje UN". Insistirajući na tome da buduća konferencija mora biti koncipirana tako da obezbedi reafirmaciju principa iz Povelje UN, jugoslovenska vlada je istovremeno smatrala potrebnim da precizira da se tu radi pre svega o načelima za koje se uporno zalažu sve nesvrstane države, „pre svega o načelu suvereniteta, nezavisnosti, ravnopravnosti, uzdržavanja od primene sile ili pritiska u međunarodnim odnosima i nemešanja u unutrašnje stvari drugih država“. S jugoslovenske strane istaknuta je i potreba da se tokom priprema za konferenciju mora izbeći blokovska isključivost i obezbediti ravnopravno učešće svih evropskih zemalja bez obzira na njihovu veličinu i vojnu i političku moć. ${ }^{8}$

U toku 1970. godine, Jugoslavija je uputila vladama evropskih država, SAD i Kanadi niz predloga u vezi sa pitanjima evropske bezbednosti i saradnje od kojih je posebno bio važan Prednacrt deklaracije o principima evropske saradnje i bezbednosti. U tom dokumentu, kao i u ostalim jugoslovenskim predlozima, insistiralo se na nekoliko političkih premisa koje bi trebale da odrede smisao i sadržaj Konferencije o evropskoj bezbednosti. Pre svega, polazilo se od stanovišta da Konferencija treba da bude skup suverenih država na kome će one ravnopravno učestvovati i odlučivati i da treba da obuhvati problematiku evropske bezbednosti i saradnje u svim njenim vidovima, a ne samo u onima za koje su blokovi trenutno zaintere-

${ }^{7}$ U Memorandumu je, 5. maja 1969, finska vlada izrazila podršku inicijativi istočnoevropskih država za održavanje Konferencije o evropskoj bezbednosti i saradnji. U Memorandumu su izložena načela na kojima bi rad te konferencije trebalo da se zasniva i predlog Finske da ona bude domaćin konferencije. Urho Kekkonnen - borac za mir, urednik Radovan Vukadinović (Zagreb: Globus, 1977), 134; Hronika međunarodnih događaja. 1969, (Beograd: Institut za međunarodnu politiku i privredu (IMPP), 1970), 1956B.

8 „Odgovor jugoslovenske vlade na Memorandum finske vlade, 25. jul 1969“, u: KEBS 77. Beogradski sastanak, priredio Boško Čolak-Antić, i dr. (Beograd: Tanjug 1977), 33. 
sovani. U tom smislu, Konferencija je morala predstavljati sastavni deo i faktor procesa radikalnog preobražaja evropskih odnosa, a ne zamrzavanja blokovske podeljenosti. Na taj način bi bili stvoreni uslovi da aktuelni ograničeni bipolarni detant dve supersile preraste u širi univerzalni detant $i$ nametne se kao globalan proces u koji bi se uključile sve države, a koji bi obuhvatao sve delove sveta i sve važne međunarodne probleme. ${ }^{9}$

\section{Inicijative za održavanje konferencije}

Inicijative za sazivanje sveevropske konferencije na kojoj bi se razmatrala opšta pitanja bezbednosti i usvojio završni dokument koji bi zapravo predstavljao neku vrstu supstituta nepotpisanog mirovnog ugovora sa Nemačkom, pokretane su od strane pojedinih istočnoevropskih država još tokom 50-ih godina. ${ }^{10}$ Njihova sadržina je uglavnom oblikovana u Moskvi, ali su ih formalno pokretali pojedini sovjetski sledbenici („Plan Rapacki“). ${ }^{11}$

Ipak, prva konkretna i precizno razrađena inicijativa za sazivanje Konferencije o evropskoj bezbednosti i saradnji pokrenuta je na zasedanju Varšavskog pakta u Bukureštu, od 4. do 6. jula 1966. Tada je usvojen poseban dokument - Zajednička deklaracija o učvršćenju mira i bezbednosti u Evropi. U tom dokumentu je inicirano što skorije održavanje „Opšteevropske konferencije“ u cilju „osiguranja bezbednosti u Evropi i uspostavljanja opšteevropske saradnje“, ali i konkretne mere koje bi trebalo u ovom kontekstu preduzeti. Bukureštanska deklaracija je uglavnom naišla na pozitivan prijem u međunarodnoj zajednici, ali je ubrzo potisnuta u drugi plan posle brutalne vojne intervencije pet članica Varšavskog pakta u Čehoslovačkoj, avgusta $1968 .^{12}$

Budući da su razlozi koji su motivisali članice Varšavskog pakta da pokrenu sazivanje KEBS i dalje postojali, na sastanku ove vojne alijanse $u$ Budimpešti, marta 1969, usvojen je novi dokument sličnog sadržaja, poznat kao Budimpeštanski apel. S obzirom na to da je nastupalo vreme kada postepeno dolazi do sve učestalijih direktnih kontakata lidera dveju supersila i

${ }^{9}$ AJ, Predsedništvo SFRJ, 803-8. Nacrt platforme SFRJ o evropskoj bezbednosti i saradnji; AJ, KPR, I-2/63. Nacrt platforme za Konferenciju o evropskoj saradnji i bezbednosti.

${ }^{10}$ Dragomir Đokić, „Kontrola naoružavanja u Evropi (predlozi i inicijative 19461969)“, u: Materijali o evropskoj bezbednosti i saradnji (Beograd: IMPP, 1969), 177-264; Vid Vukasović, „Kontrola naoružanja u Evropi (predlozi i inicijative 1946-1969)“, Materijali 0 evropskoj bezbednosti i saradnji, 177-264.

${ }^{11}$ Ljubivoje Aćimović i Sonja Dapčević-Oreščanin, Materijali o evropskoj bezbednosti i saradnji (Beograd: IMPP, 1969); Dragan Bogetić, Nova strategija spoljne politike Jugoslavije 1956-1961 (Beograd: ISI, 2006); Ljubodrag Dimić, „Josip Broz Tito, Yugoslav Policy and the Formation of the Concept of European Security 1968-1975“, in: From Helsinki to Belgrade.

12 „Zajednička deklaracija o učvršćenju mira i bezbednosti u Evropi“, Spoljnopolitička dokumentacija, god. XVIII, br. 4, (1966), 289-294. 
njihovih nastojanja da putem opsežnih pregovora pristupe rešavanju ključnih međunarodnih problema - inicijativa istočnoevropskih država je prihvaćena od Zapada. ${ }^{13}$

Posebnu ulogu u instrumentalizaciji inicijative za održavanje Konferencije o evropskoj bezbednosti i saradnji odigrala je vlada Finske, koja je 5. maja 1969. uputila Memorandum u vezi sa održavanjem ovog skupa svim evropskim državama i vladama SAD i Kanade. U tom dokumentu podržana je inicijativa istočnoevropskih država i izložena su načela na kojima bi trebalo da se zasniva konferencija. Istovremeno, Finska se ponudila da bude domaćin ovog sveevropskog skupa. ${ }^{14}$

Sazivanje skupa bilo je moguće jer je upravo u ovo vreme obezbeđena saglasnost zapadnih sila da Demokratska Republika Nemačka može učestvovati na tom skupu u svojstvu punopravnog učesnika. Do tada su zapadne sile odlučno odbacivale ovu mogućnost i stoga se pitanje modaliteta rešavanja nemačkog pitanja svodilo na jalovu verbalnu polemika Istoka i Zapada, koja je vodila stalnom odlaganju sazivanja Konferencije o evropskoj bezbednosti. Aktuelna kooperativnost Zapada u pogledu nemačkog pitanja i pitanja nepovredivosti granica bila je rezultat nešto ranije potpisanih sporazuma između SR Nemačke sa Sovjetskim Savezom, DR Nemačkom i Poljskom. S druge strane, normalizacija sovjetsko-američkih odnosa i učestali susreti Niksona i Brežnjeva, praćeni potpisivanjem niza sporazuma, aktuelizovali su interes bloka prosovjetskih država za učešćem SAD na Konferenciji, imajući u vidu da bez saglasnosti te sile nije bilo realno očekivati dogovor o bilo kojem pitanju vezanom za bezbednost i saradnju evropskih država. ${ }^{15}$

\section{Pripremni sastanak („Preliminarna konferencija“)}

Uoči Konferencije o evropskoj bezbednosti i saradnji, u cilju rešavanja tehničko-organizacionih pitanja vezanih za rad skupa, održan je u Helsinkiju Konsultativni sastanak zemalja-učesnica, koji je tekao sa kraćim prekidima od 22. novembra 1972. do 8. juna 1973. Međutim, ta „pretkonfe-

${ }^{13}$ „Apel svim evropskim zemljama u vezi sa pripremama i održavanjem opšteevropskog savetovanja za pitanja bezbednosti i saradnje u Evropi“, Spoljnopolitička dokumentacija, god. XXI, br. 2, (1969), 176-177.

${ }^{14}$ Hronika međunarodnih događaja. 1966 (Beograd: IMPP, 1967), 1022A; Godišnjak Instituta za međunarodnu politiku. 1969 (Beograd: IMPP, 1970; Spoljnopolitička dokumentacija, god XVIII, br. 4, (1966), 289-294; Isto, br. 2, 1969, 176-177.

15 AJ, KPR, I-2/54, Opšta međunarodna situacija i odnosi među velikim silama; Ljubivoje Aćimović, Problemi bezbednosti i saradnje u Evropi (Beograd: Institut za međunarodnu politiku i privredu/Prosveta, 1978); R. Petković, $n$. d.; Sava Živanov, Socijalizam i nesvrstane zemlje (Beograd, 1976). 
rencija“ $u$ velikoj meri prevazišla je prvobitnu intenciju i prerasla u značajan politički skup, koji je u osnovi odredio rad buduće konferencije. ${ }^{16}$

Tokom Pripremnog sastanka u Helsinkiju manifestovale su se krupne razlike u polaznim pregovaračkim pozicijama država učesnica. One su bile toliko velike da se dugo vremena nije videlo kako će se uopšte doći do sporazuma. Razlike su bile uslovljene različitim konkretnim interesima i dugoročnim strateškim ciljevima tih zemalja. Zemlje Varšavskog ugovora, (osim Rumunije), nastojale su da na budućoj Konferenciji sankcionišu teritorijalni i politički status kvo u Istočnoj Evropi. Zemlje NATO-a imale su cilj da se unapređenjem detanta omoguće značajne promene u Istočnoj Evropi, kako bi se na taj način prevladao postojeći status kvo u tom području. Neutralne i nesvrstane zemlje (a pre svih - Jugoslavija) videle su u Konferenciji solidan okvir za unapređenje šireg procesa saradnje u Evropi uporedo sa značajnim menjanjem postojećeg stanja sa naglašenim blokovskim i hladnoratovskim obeležjima. Dakle, SSSR i njegovi saveznici su želeli konsolidaciju i učvršćenje postojećeg status kvoa, NATO je želeo promene, ali samo na jednoj strani - na Istoku, a vanblokovske zemlje su želele radikalne promene na obe strane blokovske demarkacione linije, odnosno u Evropi u celini. ${ }^{17}$

Jugoslovenska delegacija je tokom Konsultativnog sastanka, zajedno sa grupom nesvrstanih i neutralnih evropskih država, odigrala zapaženu ulogu u premošćavanju stalne blokovske isključivosti, koja je povremeno ozbiljno dovodila u pitanje proces usaglašavanja stavova učesnika konferencije oko ključnih pitanja organizovanja ovog evropskog skupa. Grupa od osam vanblokovskih država često je preuzimala ulogu nezaobilaznog posrednika između konfrontiranih blokova, ali i konstruktivnog inicijatora niza predloga koji su u velikoj meri odredili sadržaj Konferencije i usvojenih dokumenata. $^{18}$

Posle šestomesečne debate ambasadori 34 države-učesnice ${ }^{19}$ usvojili su Završne preporuke Helsinških konsultacija. To je bio detaljno razrađen

${ }^{16}$ Iako su svi učesnici pregovora u Helsinkiju naglašavali da se te pripremne konsultacije ne smeju smatrati „preliminarnom konferencijom“ - one su poprimile upravo takvu fizionomiju. Konsultacije nisu bile nužne samo zbog organizovanja predstojeće konferencije, nego su bile važne i zbog usvajanja dnevnog reda i izrade nacrta instrukcija koje se odnose na Konferenciju. Urho Kekkonnen - borac za mir, 136-139.

${ }^{17} \mathrm{Lj}$. Aćimović, $n$. d., 139-148.

${ }^{18}$ R. Petković, $n$. d.; T. Ficher, op. cit.

${ }^{19} \mathrm{Na}$ Konsultativnom sastanku u Helsinkiju učestvovale su sve evropske države osim Albanije i Monaka. Monako se, međutim, uključio u rad Konferencije o evropskoj bezbednosti i saradnji već u momentu kada je otpočela prva faza tog skupa, jula 1973. Albanija je bila jedina evropska zemlja koja je odbila da učestvuje na Konferenciji. U više navrata albanska vlada je isticala „da su inicijatori Konferencije američki imperijalizam i sovjetski soc-imperijalizam, upravo oni koji održavaju u životu agresivne blokove NATO pakt i Varšavski ugovor“. Stoga su u Tirani Konferenciju okarakterisali kao „komediju koja ima ritam 
dokument, čijim su odredbama regulisana sva pitanja od značaja za sazivanje i rad Konferencije, kao što su njena organizacija, dnevni red, učesnici, datum i mesto održavanja, poslovnik, pravila procedure i finansijski aranžmani. Ovim preporukama je predviđeno - u duhu predloga za koji se zalagala Francuska - da se konferencija održi u tri faze na tri različita diplomatska nivoa. Prvu fazu bi činio sastanak ministara inostranih poslova u Helsinkiju, koji bi usvojili pravila i proceduru, dnevni red i instrukcije za radna tela konferencije i podneli predloge o temama za dnevni red druge faze konferencije. Druga faza bi se svela na rad u stručnim komisijama i potkomisijama u Ženevi, radi konkretnog dogovora o svim ključnim pitanjima i izradi projekata i završnih dokumenata. I na kraju, treća, završna faza bi predstavljala sastanak šefova država ili vlada na kome bi svečano bili usvojeni završni dokumenti konferencije. ${ }^{20}$

Odlučeno je da prva faza Konferencije za evropsku bezbednost i saradnju (KEBS), kako je zvanično usvojen naziv, počne 3. jula 1973. u Helsinkiju. Finska vlada je preuzela obavezu da uputi pozive svim evropskim državama, SAD i Kanadi. ${ }^{21}$

Predviđeno je da se dnevni red Konferencije svede na četiri tačke, četiri velike teme, koje su kasnije, zbog svoje kompleksnosti i obimnosti, često nazivane „korpe“. S obzirom na suprotstavljena i najčešće inkompatibilna gledišta dveju blokovskih sila u pogledu svih važnijih pitanja koja je trebalo razmatrati na Konferenciji - sve četiri tačke dnevnog reda bile su formulisane tako da se iz njihovih naziva nije moglo jasno nazreti ono suštinsko, što će činiti okosnicu debate i zbog čega je, zapravo, Konferencija i sazvana.

1) U tom smislu, prva tačka dnevnog reda je svedena na formulaciju - „problem bezbednosti u Evropi“, iako se tu centralno pitanje odnosilo ne nepovredivost i nepromenjivost posleratnih granica, zbog kojeg su istočnoevropske države godinama forsirale održavanje ove konferencije. Te zemlje su, naime, u budućem završnom aktu Konferencije videle supstitut neostvarenog mirovnog ugovora sa Nemačkom. Sovjetski Savez i njegovi saveznici su želeli da se kroz rešenja usvojena na Konferenciji o evropskoj bez-

pacifističkog tam-tama supersila“. KEBS 77. Beogradski sastanak, 38-39, 171; Hronika međunarodnih događaja. 1972 (Beograd: IMPP, 1973), 3154A; AJ, Predsedništvo SFRJ, 803-608, Informacija o stavovima zemalja učesnica na Pripremnoj konferenciji u Helsinkiju o evropskoj saradnji i bezbednosti.

${ }^{20}$ AJ, KPR, I-2/63, Završne preporuke sa Konsultovanja u Helsinkiju; AJ, Predsedništvo SFRJ, 803-7, Izveštaj o multilateralnim pripremnim razgovorima za KEB; AJ, KPR, I2/63, Izveštaj o drugoj fazi multilateralnih razgovora na KEB u Helsinkiju od 15. januara do 9. februara 1973; Isto, O rezultatima Pripremnih razgovora u Helsinkiju; isto. Izveštaj o multilateralnim pripremama KEBS, Helsinki, 22. novembar 1972-8. jun 1973.

${ }^{21}$ Urho Kekkonnen - borac za mir, 138-140. 
bednosti trajno obezbedi multilateralno sankcionisanje teritorijalnopolitičkog status kvoa u Evropi.

2) Druga tačka dnevnog reda je obuhvatala razmatranje „pitanja saradnje u oblasti privrede, nauke i tehnologije i zaštite čovekove okoline". Centralno mesto je zapravo imalo razmatranje problema „klauzule najvećeg povlašćenja“ - koncesije koje su od zapadnih zemalja tražile istočnoevropske države (članice SEV-a) i poštovanje načela punog reciprociteta u trgovini, što je, pak, bio uslov Zapada za pružanje pomenute koncesije Istoku. Dakle, tu se radilo o unapređenju ekonomske saradnje evropskih država kroz postepeno neutralisanje negativnog dejstva regionalnog zatvaranja zapadnih i istočnoevropskih organizacija (na čemu je insistirao Istok) i liberalizaciji postojećeg sistema trgovinske razmene (što je bio zahtev Zapada). Pa ipak, u ovoj sferi pregovora se ponajmanje osećalo negativno dejstvo ideološko-političkog razmimoilaženja među blokovskim formacijama i preliminarni dogovori o ovoj temi su u Helsinkiju relativno brzo i uspešno okončani. ${ }^{22}$

3) Ideološka i politička konfrontacija dva bloka posebno je došla do izražaja u vezi sa trećom tačkom dnevnog reda - „saradnje $u$ humanitarnim pitanjima u oblasti ljudskih kontakata, informacija, kulture i obrazovanja“. Iza ove formulacije krilo se, u stvari, pitanje obezbeđivanja slobodnog kretanja ljudi i ideja preko nacionalnih granica - na čemu su uporno insistirale zapadne zemlje, uslovljavajući dogovor o prvoj tački dnevnog reda značajnim sovjetskim koncesijama u pogledu poštovanja ljudskih prava i osnovnih sloboda, uključujući i slobodu misli i ubeđenja. Zapad je insistirao na tome da se uklone sve prepreke slobodnijem širenju svih vrsta informacija i ideja, da se poboljša rad stranih dopisnika, da se obezbedi slobodno rasturanje knjige, časopisa i novina, da se ukinu smetnje slobodnom emitovanju stranih radio-stanica i organizovanju zajedničkih TV diskusija. Slobodnija razmena informacija i ideja između evropskih zemalja, na Zapadu je tumačena kao važan preduslov boljem međusobnom upoznavanju država i naroda Evrope. Međutim, to je, zapravo, bio put koji je Zapadu obezbeđivao veći ideološki prodor u Istočnu Evropu i stvarao politički okvir koji bi neminovno vodio slabljenju unutrašnje kohezije i discipline u prosovjetskom bloku. $S$ druge strane, obezbeđivanjem prava na slobodno kretanja ljudi (u koje je uključeno i njihovo pravo da napuste zemlju - „olakšice u vezi iseljavanja“), bili bi stvoreni uslovi koji su trebali da potencijalno olakšaju iseljavanje

${ }^{22}$ AJ, KPR, I-2/63, Završne preporuke sa Konsultovanja u Helsinkiju; AJ, Predsedništvo SFRJ, 803-7, Izveštaj o multilateralnim pripremnim razgovorima za KEB; AJ, KPR, I2/63, Izveštaj o drugoj fazi multilateralnih razgovora na KEB u Helsinkiju od 15. januara do 9. februara 1973; Isto, O rezultatima Pripremnih razgovora u Helsinkiju; Isto, Izveštaj o multilateralnim pripremama KEBS, Helsinki, 22. novembar 1972-8. jun 1973. 
Jevreja koji su živeli u Sovjetskom Savezu u zapadne države ili u Izrael, na čemu su posebno insistirali pojedini kongresmeni u SAD. Razmatranje pitanja "spajanja porodica“ i obezbeđivanja „redovnih kontakata na osnovu porodičnih veza", u sklopu ove tačke dnevnog reda, bilo je od posebnog značaja za brojne nemačke familije koje su po okončanju rata živele odvojeno u dve nemačke države, bez mogućnosti direktnih ličnih kontakata i svakodnevne komunikacije. $^{23}$

4) Četvrta tačka dnevnog reda - „pitanje kontinuiteta Konferencije“, svodila se na potrebu da se pregovarački proces o evropskoj bezbednosti nastavi i posle okončanja konferencije i da se u tu svrhu formiraju posebna tela koja bi činila srž institucionalizacije, odnosno organizovanog nastavljanja ovog multilateralnog procesa. ${ }^{24}$

Ideja o „konferenciji posle konferencije“ bila je osmišljena u Beogradu, a snažno podržana od strane grupe nesvrstanih i neutralnih država na KEBS-u. Tokom Konsultativnog sastanka u Helsinkiju jugoslovenska delegacija je insistirala na tome da se posle Konferencije nastavi rad na tekućem usklađivanju suprotnih i neusaglašenih stavova i da se pristupi iznalaženju rešenja za nove probleme koji će naknadno iskrsnuti. Pri tome se polazilo od stanovišta da je za efikasno sprovođenje odluka Konferencije i njihovog daljeg nadograđivanja neophodno formirati posebna tela koja će za to biti zadužena, koja će pratiti proces realizacije pomenutih odluka i zakazivati nove sastanke zemalja učesnica Konferencije, kako bi akcija započeta u Helsinkiju prerasla u dugoročni proces, a Konferencija - u organizaciju. Zbog ovakvog nastupa Jugoslavije tokom priprema za Konferenciju i tokom njenog održavanja - u znak priznanja, doneta je odluka da se u Beogradu, tokom 1977. godine, održi naredni skup evropskih država, koji bi predstavljao neku vrstu nastavka Helsinške konferencije. ${ }^{25}$

$\mathrm{Pa}$, ipak, jugoslovenska inicijativa na Pripremnom sastanku u Helsinkiju, da se na predstojećoj Konferenciji razmotri pitanje kontinuiteta te konferencije i formiranja institucionalnih mehanizama u tu svrhu - samo je delimično prihvaćena. Dogovoreno je, naime, da se to pitanje razmotri na Konferenciji u okviru posebne, četvrte tačke dnevnog reda. Ali, formulacije koje su se odnosile na tu tačku dnevnog reda bile su krajnje neodređene i uopštene, tako da same po sebi nisu nagoveštavale kasniji ozbiljniji iskorak

${ }^{23}$ Lj. Aćimović, n. d.; Godišnjak Instituta za međunarodnu politiku i privredu. 1974, (Beograd: IMPP, 1975), 87-88, 91, 93.

${ }^{24}$ AJ, KPR, I-2/63, Završne preporuke sa Konsultovanja u Helsinkiju; AJ, Predsedništvo SFRJ, 803-7, Izveštaj o multilateralnim pripremnim razgovorima za KEB; AJ, KPR, I2/63, Izveštaj o drugoj fazi multilateralnih razgovora na KEB u Helsinkiju od 15. januara do 9. februara 1973; Isto, O rezultatima Pripremnih razgovora u Helsinkiju; Isto, Izveštaj o multilateralnim pripremama KEBS, Helsinki, 22. novembar 1972-8. jun 1973.

${ }^{25}$ T. Ficher, op. cit. 
u tom kontekstu. Radilo se zapravo o nespremnosti blokovskih formacija da se konkretnije obavežu u pogledu budućeg organizovanog sistema političkih pregovora u koji bi bile uključene sve evropske države. Dok su istočnoevropske države dozvoljavale mogućnost eventualnog povremenog sazivanja sveevropskih skupova, zapadne sile su ispoljavale krajnje rezervisan stav i suprotstavljale su se svakom rešenju koje bi vodilo institucionalizaciji ovog pregovaračkog procesa. ${ }^{26}$

Inače, kada je reč o nastupu Jugoslavije zajedno sa grupom nesvrstanih i neutralnih država tokom Konsultativnog sastanka u Helsinkiju, posebno je vredan pažnje rezultat ostvaren prilikom usvajanje „demokratskih pravila procedure“. Da bi se eliminisala mogućnost nadglasavanja i nametanje odluka koje bi bile od interesa isključivo za blokovske formacije - ova grupa zemalja je insistirala na tome da se sve odluke donose isključivo na osnovu pravila opšte saglasnosti (konsenzusa). Odlučivanje na osnovu opšte saglasnosti obezbeđivalo je puno uvažavanje interesa svih učesnika Konferencije i punu ravnopravnost država bez obzira na njihovu veličinu i vojnu i ekonomsku moć. Glasanje na osnovu proste većine (za šta su se zalagale zapadne države) - značilo bi diktat jednog (brojnijeg) bloka, što prirodno ne bi bilo prihvatljivo za drugi blok, dok bi glasanje na osnovu kvalifikovane većine (na čemu su insistirale istočnoevropske države) predstavljalo diktat oba bloka, što, opet, ne bi bilo prihvatljivo za vanblokovske države i svodilo bi se na rešenja koja bi imala izrazito blokovski karakter. Sistem nadglasavanja i nametanja stavova većine („diktatura većine"), kakav je, inače, bio zastupljen u Generalnoj skupštini Ujedinjenih nacija, pokazao se u praksi međunarodnih odnosa nesvrsishodan, jer donete odluke nisu imale obavezujuću pravnu snagu i one države koje nisu glasala za njih odbijale su da ih sprovode u život. Stoga, sistem odlučivanja putem konsenzusa (inače ustaljen u okviru Pokreta nesvrstanosti) - iako je najčešće iziskivao više vremena i dug proces usaglašavanja gledišta - obezbeđivao je brži proces rešavanja važnih međunarodnih problema nego sistem donošenja odluka prostom ili kvalifikovanom većinom. S druge strane, on je $\mathrm{u}$ datim okolnosti potencijalno mogao pružiti značajan doprinos demokratizaciji rada buduće evropske konferencije. Loša strana ovakvog sistema odlučivanja, pak, bila je ta što je vodio donošenju suviše uopštenih, neodređenih i nepreciznih odluka, koje je kasnije teško bilo sprovoditi u praksi, jer bi ih svako tumačio na svoj način i davao im smisao koji njemu

${ }^{26}$ AJ, KPR, I-2/63, Završne preporuke sa Konsultovanja u Helsinkiju; AJ, Predsedništvo SFRJ, 803-7, Izveštaj o multilateralnim pripremnim razgovorima za KEB; AJ, KPR, I2/63, Izveštaj o drugoj fazi multilateralnih razgovora na KEB u Helsinkiju od 15. januara do 9. februara 1973; Isto, O rezultatima Pripremnih razgovora u Helsinkiju; Isto, Izveštaj o multilateralnim pripremama KEBS, Helsinki, 22. novembar 1972-8. jun 1973. 
odgovara. Uz to, ograničenost sistema odlučivanja putem konsenzusa proizilazila je i iz toga što je takav sistem bilo moguće primenjivati samo u slučaju da postoji izuzetno veliki interes svih učesnika da se problemi koji su na dnevnom redu u celini razreše. ${ }^{27}$

Uloga Jugoslavije i nesvrstanih i neutralnih država u koncipiranju Završnih preporuka Helsinških konsultacija posebno je došla do izražaja tokom debate o sadržaju dnevnog reda i prioritetima Konferencije o evropskoj bezbednosti i saradnji. Te zemlje su insistirale na proširivanju dnevnog reda na vojne aspekte bezbednosti u Evropi i na uporednom razmatranju i povezivanju vojnih i političkih aspekata evropske bezbednosti (blokovske sile nisu ispoljavale interes da vojna pitanja budu razmatrana na Konferenciji). ${ }^{28}$ Zahvaljujući pomenutoj inicijativi, u Završne preporuke Helsinških konsultacija uključeno je posebno poglavlje u kome je predviđeno usvajanje „mera za jačanje poverenja“ - prethodna notifikacija većih vojnih manevara zemalja učesnica Konferencije, razmena posmatrača na manevrima, obaveštavanje o većim pokretima trupa, kao i razmatranje političkih vidova smanjenja oružanih snaga i naoružanja u Evropi. ${ }^{29}$

Jugoslavija se suprotstavljala nastojanjima dvaju blokova da se debata na Konferenciji o evropskoj bezbednosti ograniči na iznalaženje obostrano prihvatljivih kompromisa isključivo u vezi sa užim područjem Centralne Evrope. Predstavnici Jugoslavije, Kipra i Malte su na Konsultativnom sastanku u Helsinkiju insistirali na uključivanju „mediteranske komponente" u pojam evropske bezbednosti, s obzirom na to da je u Evropi teško bilo ostvariti bezbednost u uslovima kada je Mediteran bio poprište konfrontacije velikih sila i žarište oštrih lokalnih sukoba (kriza na Bliskom istoku, Kiparska kriza). Zalagali su se za univerzalna rešenja koja bi se ticala ne samo striktno evropskog prostora nego i Balkana i Mediterana, pa i područja Bliskog istoka. Doduše jugoslovenski predlog da se u rad Konferencije uključe i vanevropske, mediteranske zemlje, nije prihvaćen. Dogovoreno je, međutim, da te zemlje mogu učestvovati u delu debate koji bi se ticao bezbednosti Mediterana. ${ }^{30}$

${ }^{27}$ Isto; Lj. Dimić, „Josip Broz Tito, Yugoslav Policy and the Formation of the Concept of European Security 1968-1975“.

${ }^{28}$ Smatrale su da pregovori o razoružanju treba da zadrže uži bilateralni karakter i da u njima treba da učestvuju samo predstavnici blokovskih formacija. Uključivanje ostalih evropskih država u pregovore, u tom smislu, samo bi otežalo postizanje obostrano prihvatljivih kompromisa. AJ, KPR, I-2/63, Vojni aspekti evropske bezbednosti.

${ }^{29}$ AJ, Predsedništvo SFRJ, 803-7, Izveštaj o multilateralnim pripremnim razgovorima za KEB; AJ, KPR, I-2/63, Izveštaj o drugoj fazi multilateralnih razgovora na KEB u Helsinkiju od 15. januara do 9. februara 1973; Isto, O rezultatima Pripremnih razgovora u Helsinkiju; Isto, Izveštaj o multilateralnim pripremama KEBS, Helsinki, 22. novembar 1972-8. jun 1973.

${ }^{30}$ Godišnjak Instituta za međunarodnu politiku i privredu. 1975, (Beograd: IMPP, 1976), 90 . 


\section{Prva faza KEBS-a - otvaranje konferencije}

Prva faza KEBS-a održana je u Helsinkiju od 3. do 7. jula 1973. na nivou ministara inostranih poslova. Ukupno 35 zemalja je zvanično prihvatilo poziv da učestvuju na ovom četvorodnevnom skupu (sve evropske zemlje osim Albanije, koja nije učestvovala ni na pripremnom sastanku). Na sastanku formalno je, bez ikakvih izmena, usvojen tekst Završne preporuke Helsinških konsultacija i reafirmisani opšti stavovi koji su usvojeni na Pripremnom sastanku, okončanom mesec dana ranije. Usvojeni su modaliteti procedure, opšta pravila, dnevni red i instrukcije za radna tela Konferencije.

Ministri zemalja učesnica su podneli svoje predloge tekstova za izradu dokumenata za narednu fazu Konferencije. Kada je u pitanju prva tačka dnevnog reda („problem bezbednosti u Evropi“), najvažniji su bili predlozi koji su se ticali pripreme bazičnog dokumenta Konferencije - o „principima odnosa između država učesnica“. Postignuta je saglasnost da ovaj dokument treba da sadrži sledećih deset principa - suverena jednakost i poštovanje prava svojstvenih suverenitetu, uzdržavanje od pretnje silom ili upotrebe sile, nepovredivost granica, teritorijalni integritet država, mirno rešavanje sporova, nemešanje $u$ unutrašnje poslove, poštovanje ljudskih prava i osnovnih sloboda, uključujući i slobodu misli, savesti, veroispovesti i ubeđenja, ravnopravnost i pravo naroda na samoopredeljenje, saradnja među državama i savesno ispunjavanje obaveza po međunarodnom pravu. ${ }^{31}$

Već na prvi pogled uočljivo je da je postignut kompromis između stava Istoka o nepovredivosti granica i stava Zapada koji je insistirao na poštovanju principa ljudskih prava i osnovnih sloboda. Oba principa su uneta u nacrt buduće deklaracije.

Preostali principi, koji su i inače u većoj ili manjoj meri bili komplementarni sa pomenuta dva, uneti su u nacrt završnog akta delimično i zahvaljujući aktivnosti jugoslovenske delegacije. Naime, neutralne i nesvrstane zemlje su podržale predlog jugoslovenskog ministra inostranih poslova Miloša Minića, izložen u jugoslovenskom „Nacrtu deklaracije o principima kojima se zemlje-učesnice rukovode u svojim odnosima“. ${ }^{32}$ Obrazlažući intenciju ovog dokumenta, Minić je istakao potrebu za reafirmacijom demokratskih načela međunarodnih odnosa na kojima se zasniva Povelja UN. Srazmerno tome koliko su ova načela bila i dalje aktuelna, Miniću se činila "prevaziđenom" i „anahronom" blokovska podela sveta i nastojanja velikih sila da mimo volje ostalih država prekrajaju kartu sveta. Minićev

${ }^{31}$ Godišnjak Instituta za međunarodnu politiku i privredu. 1974, 80.

32 AJ, Predsedništvo SFRJ, 803-8, Nacrt platforme SFRJ o evropskoj bezbednosti i saradnji. 
nastup je, zapravo, predstavljao poziv na izgradnju novog demokratskog sistema u Evropi u kome bi odnosi evropskih država „počivali na sigurnim i trajnim temeljima, lišenim sadašnje blokovske podeljenosti“ “. ${ }^{33}$

Tokom prve faze pregovora evropskih zemalja, ministri inostranih poslova su odlučili da se KEBS nastavi i da druga faza počne 18. septembra 1973. u Ženevi. Stručnim telima koja su trebala da preuzmu ulogu pregovarača naloženo je da izrade predloge završnih dokumenata na osnovu Preporuka Helsinških konsultacija, da bi ti dokumenti bili usvojeni u trećoj fazi KEBS-a, u Helsinkiju.

Politički krugovi u Beogradu su procenjivali da prva faza KEBS-a ministarski skup u Helsinkiju, predstavlja samo „polaznu tačku“ u evropskom pregovaračkom procesu i „zbrzani kompromis na nivou ministara“, koji je samo definisao glavna pitanja o kojima treba raspravljati, ali ne i okvirna rešenja. Gledano iz današnje perspektive, ovakva procena čini se ispravnom. Umesto radnog dokumenta koji je trebalo da bude upućen stručnjacima na doradu tokom druge faze KEBS-a, ministri inostranih poslova u Helsinkiju su sačinili samo popis niza kontroverznih problema, nešto više nego razrađen dnevni red. Na osnovu formulacija koje su bile tendenciozno dvosmislene da bi mogle objediniti stavove koji se ne poklapaju, prepušteno je stručnim telima da sve to razrade, razmotre i uobliče u završni dokument koji su tokom treće faze KEBS trebali svečano da usvoje šefovi vlada ili država evropskih zemalja. To je značilo da će stručnjaci za ova pitanja praktično morati da ceo posao otpočnu ispočetka i preuzmu odgovornost koju su sa sebe skinuli ministri inostranih poslova. Koliko je to bio težak i teško ostvarljiv zadatak, pokazalo se tokom naredne faze KEBS-a.

\section{Druga faza konferencije - faza pregovora}

Druga faza KEBS-a počela je 18. septembra 1973, a završena 21. jula 1975. u Ženevi. Tokom ove faze predstavnici 35 zemalja radili su u nizu stalnih radnih tela u okviru posebnih stručnih komisija i potkomisija. Delegacije su trebale da razrade i konkretizuju Završne preporuke Helsinških konsultacija i omoguće njihovo konačno uobličavanje u vidu predloga Završnog dokumenta, odnosno projekta zaključaka KEBS-a. Reč je o četiri grupe predloga i zaključaka koje obuhvataju: (1) vojno-političku bezbednost i saradnju, (2) ekonomsku, naučnu i tehnološku saradnju, (3) saradnju u

${ }^{33}$ AJ, KPR, I-2/63, Govor potpredsednika Saveznog izvršnog veća i saveznog sekretara za inostrane poslove SFRJ Miloša Minića na Konferenciji ministara inostranih poslova, u okviru prve faze KEBS-a, Helsinki, 5. jul 1973; „Govor saveznog sekretara za inostrane poslove SFRJ Miloša Minića na prvoj fazi Konferencije o evropskoj bezbednosti i saradnji“, Spoljnopolitička dokumentacija, god. XXV, br. 2, (1973), 111-112. 
oblasti ljudskih kontakta, informacija, kulture i obrazovanja i (4) kontinuitet Konferencije.

Ovom formalnom početku druge faze prethodilo je, u periodu između 29. avgusta i 3. septembra 1973, nekoliko sednica najvišeg organa Konferencije - Koordinacionog komiteta, sastavljenog od šefova delegacija svih država učesnica, na kojima su donete glavne odluke o organizaciji druge faze Konferencije. Na tim sastancima relativno je lako postignuta saglasnost da se rad Konferencije odvija u četiri komiteta, formirana prema pomenutim osnovnim oblastima dnevnog reda. Svaki od ovih komiteta imao je u svom sastavu i odgovarajući broj potkomiteta, odnosno radnih grupa (tri u prvom komitetu, pet u drugom, četiri u trećem). Nešto kasnije, formirane su i posebne radne grupe za Mediteran i održavanje kontinuiteta Konferencije. $^{34}$

Znatno težim se, međutim, pokazalo razmatranje drugog pitanja koje se našlo pred Koordinacionim komitetom, a koje se ticalo sprovođenja $\mathrm{u}$ život načelne odluke o pozivanju neevropskih mediteranskih zemalja da učestvuju na Konferenciji (na čemu su posebno insistirale nesvrstane države: Jugoslavija, Kipar i Malta). To pitanje je bilo predmet spora i tokom prve faze pregovora u Helsinkiju. Ipak, problem je rešen usvajanjem kompromisa, koji je ozvaničen neposredno posle otvaranja druge faze pregovora. Zapadne zemlje su se saglasile da na KEBS-u učestvuju arapske mediteranske države: Alžir, Egipat, Sirija, Maroko i Tunis, ali uz uslov da na skupu uzme učešća i Izrael (što su prihvatile ostale evropske države). ${ }^{35}$

Jugoslovenska delegacija, na čijem čelu se nalazio savetnik saveznog sekretara za inostrane poslove ambasador Đuro Ninčić, očigledno je bila instruisana od svoje vlade da mora biti aktivna u svim fazama generalne debate o svim relevantnim pitanjima dnevnog reda, a istovremeno, da mora biti prisutna i u svim domenima izrade završnog dokumenta. Stoga je jugoslovenska delegacija tokom skupa u Ženevi podnela čitav niz predloga i pokrenula niz inicijativa, trudeći se da na taj način promoviše jugoslovenske spoljnopolitičke prioritete i ciljeve za koje se zalagao Pokret nesvrstanosti. ${ }^{36}$

${ }^{34}$ Godišnjak Instituta za međunarodnu politiku i privredu. 1975, 66; AJ, KPR, I-2/63, Izveštaj o Konferenciji o bezbednosti i saradnji.

35 DA MSP, PA, Jugoslavija, 1974, fasc. 176, sign. 41359, Problem Mediterana (Informacija o dosadašnjem radu II faze KEBS, 19. decembar 1973); AJ, KPR, I-2/63, Pitanja koja se tiču bezbednosti i saradnje u Sredozemlju.

${ }^{36} \mathrm{U}$ tom smislu, u okviru prve tačke dnevnog reda Jugoslavija je podnela nacrt deklaracije o principima kojima će se rukovoditi države učesnice u svojim odnosima (tekst je podnet u Helsinkiju, a obnovljen u Ženevi), nacrt rezolucije o vojnim aspektima bezbednosti (zajednički predlog Austrije, Finske, Jugoslavije, Kipra, Švajcarske i Švedske), nacrt rezolucije o bezbednosti i saradnji na Mediteranu (zajedno sa Kiprom i Maltom), nacrt rezolucije o 
Bez obzira na izuzetno široko polje aktivnosti jugoslovenskih predstavnika na KEBS-u, zvaničnici iz Beograda su poseban značaj pridavali nesumnjivo najosetljivijem pitanju na Konferenciji, koje je već na samom početku debate u Ženevi imalo takoreći centralno mesto i koje je bilo rešeno već tokom prvog dela redakcijskog rada u odborima. Reč je o pitanju granica. To pitanje je za Jugoslaviju posebno dobilo na aktuelnosti budući da je upravo u vreme održavanja Konferencije u Ženevi došlo do novih tenzija u jugoslovensko-italijanskim odnosima oko provizorne granice u rejonu Trsta, ustanovljene Londonskim memorandumom, avgusta $1954 .{ }^{37}$

Po pitanju nepovredivosti granica u prvom momentu došlo je do oštre polarizacije blokovskih gledišta. Istočnoevropske zemlje su insistirale na tome da se postojeće granice, uspostavljene posle Drugog svetskog rata, moraju poštovati i ne smeju se više ni pod kakvim uslovima menjati. Time je proklamovano ne samo načelo nepovredivosti granica, nego i princip njihove nepromenjivosti. Zapad je, pak, zastupao gledište da treba ostaviti mogućnost menjanja granica zakonitim putem (putem međunarodnih sporazuma) i „da treba ostaviti otvoreno pitanje definitivnosti postojećih granica“, čime se implicitno sugerisala provizornost linije razgraničenja pojedinih država. Članice Evropske ekonomske zajednice su tu, pre svega, imale u vidu opciju kasnijeg nemačkog ujedinjenja, ali i viziju teritorijalne integracije Zapadne Evrope. Takva opcija, naravno, nije bila prihvatljiva za lidere Istočnog bloka, upravo zato što je nagoveštavala mogućnost ujedinjenja dve nemačke države putem sporazuma legitimnih predstavnika nemačkog naroda (mimo volje Sovjetskog Saveza). S druge strane, rešenje koje je zagovarao Zapad nije vodilo trajnom multilateralnom fiksiranju aktuelne

kolonijalizmu i nacrt deklaracije o nacionalnim manjinama. U okviru druge tačke dnevnog reda, podnela je sledeće predloge: nacrt rezolucije o saradnji država učesnica sa zemljama u razvoju, predlog o industrijskoj saradnji i projektima od zajedničkog interesa i predlog o rešavanju pitanja vezanih za migraciju radnika. U okviru treće tačke dnevnog reda - podnet je predlog o saradnji država učesnica u oblasti informacija, kulture i nauke. I, na kraju, u okviru četvrte tačke dnevnog reda, jugoslovenska delegacija je podnela nacrt rezolucije o kontinuitetu KEBS-a. DA MSP, PA, Jugoslavija, 1974, fasc. 176, sign. 417633, Informacija delegacije SFRJ o radu II faze KEBS-a; KEBS 77. Beogradski sastanak, 46-47.

${ }^{37}$ Ponovna eskalacija tršćanske krize dostigla je najvišu tačku u proleće 1974. Ali, elementi oštre jugoslovensko-italijanske konfrontacije oko nekadašnje Zone B bili su prisutni i tokom 1973. godine. Jugoslovensko-italijanski spor je postepeno poprimao obrise ozbiljnog sukoba na relaciji Jugoslavija-NATO. Do ovakvog obrta došlo je zbog toga što su upravo $\mathrm{u}$ ovo vreme organizovani manevri amfibijskih snaga NATO u oblasti Tršćanskog zaliva. Zvaničnici iz Beograda su optužili SAD i NATO da su se, opredeljujući se za akciju u momentu kada je kriza na ovom prostoru opasno eskalirala, svrstali na italijansku stranu. Od tog momenta spor između Jugoslavije i Italije dobija novu, širu dimenziju i još ozbiljniji karakter. U tom smislu, stav o nepovredivosti granica implicirao je potrebu regulisanja aktuelne granice sa Italijom. Dragan Bogetić, „Tršćanska kriza 1974. i pogoršanje jugoslovensko-američkih odnosa“, Istorija 20. veka, br. 1, (2015), 95-110. 
granice između Poljske i Nemačke (granice između Istoka i Zapada), što je predstavljalo glavni motiv zbog kojeg su istočnoevropske zemlje učestvovale na Konferenciji i svojevremeno je inicirale. ${ }^{38}$

Jugoslavija je izrazito bila protiv rešenja koje je zagovarao Zapad. Takvo rešenje je tumačeno kao nastojanje da se celokupno postojeće teritorijalno stanje u Evropi predstavi kao polazna i prelazna faza ka nekakvom novom stanju do koga se može doći dogovorom velikih sila. Insistiranje na provizornosti granica posebno je bilo neprihvatljivo za Jugoslaviju u momentu kada je Italija osporavala međunarodno-pravni status svoje granice prema Jugoslaviji. S druge strane, u političkim krugovima u Beogradu preovladavalo je i gledište da je nemogućno jednom za svagda zamrznuti određeno stanje vezano za svaki pojedinačni slučaj. Stoga je jugoslovenska delegacija predložila kompromisnu formulaciju, prihvatljivu za obe strane, i za NATO, i za Varšavski pakt. Ta formulacija, podržana od ostalih vanblokovskih država i Rumunije, polazila je od imperativa očuvanja i nepovredivosti postojećih granica (isključena je svaka mogućnost nasilnog menjanja granica), ali je istovremeno dozvoljavala da se u specifičnim slučajevima obezbedi mogućnost promene granica sporazumom svih zainteresovanih aktera. ${ }^{39}$ Uz manje korekcije, ovo rešenje uneto je u Završni dokument iz Helsinkija. ${ }^{40}$

Nade Zapada da će za dobijeno priznanje nepovredivosti posleratnih granica Sovjetski Savez uzvratiti adekvatnim ustupcima u domenu „slobodne cirkulacije ljudi i ideja" - nisu se ispunile. Desilo se, zapravo, sasvim suprotno. SSSR i njegovi saveznici, pošto su postigli ono zbog čega su došli na Konferenciju, ispoljavali su totalnu nezainteresovanost oko izrade završnih tekstova kojima bi se regulisala i ostala pitanja sa dnevnog reda Konferencije. Prelazak sa debate na redakcioni rad bio je onemogućen njihovim namernim usporavanjem i odugovlačenjem diskusije, uz stalno otvaranje novih tema oko kojih je bilo očigledno da se ne može postići saglasnost svih učesnika. Tako, u dva navrata - krajem decembra 1973. i u leto 1974 dolazi do potpune blokade $u$ radu stručnih tela, koja je izazvala ozbiljnu krizu daljeg pregovaračkog procesa. Umesto da se druga faza Konferencije završi krajem 1973, ona se produžila na skoro dve godine (trajala je 22 meseca). Doduše, ta kriza u radu Konferencije bila je rezultat negativnog

${ }^{38}$ DA MSP, PA, Jugoslavija, 1974, fasc. 176, sign. 417 633, Princip nepovredivosti granica (Informacija delegacije SFRJ o radu II faze KEBS, 15. januar-6. april 1974); AJ, KPR, I-2/63, Opšti osvrt na II fazu Konferencije o evropskoj bezbednosti i saradnji; Godišnjak Instituta za međunarodnu politiku i privredu. 1975, 88-89.

${ }^{39}$ AJ, Predsedništvo SFRJ, 803-26, Mogućnost sporazumne izmene granica.

40 „Završni akt Konferencije o bezbednosti i saradnji u Evropi”, u: Konferencija o evropskoj bezbednosti i saradnji, Dokumenti KEBS: 1975-1995, urednik Branislav Milinković (Beograd: Međunarodna politika i dr., 1995), 11-12. 
delovanja niza drugih faktora: obimnosti i složenosti razmatrane materije, proceduralnih teškoća vezanih za mukotrpan proces usaglašavanja suprotstavljenih gledišta putem konsenzusa, Kiparske krize, izbijanja četvrtog po redu arapsko-izraelskog rata, oštre konfrontacije Sever-Jug u sklopu dramatične eskalacije energetske krize, smrti predsednika Žorža Pompidua (Georges Pompidou) i izbora novog predsednika Francuske, ostavke nemačkog kancelara Vilija Branta (Willy Brandt) i ostavke američkog predsednika Niksona povodom „afere Votergejt“ („Affair Watergate“), koja je ozbiljno uzdrmala američko društvo. ${ }^{41}$

Sve učestaliji zastoji u radu stručnih tela Konferencije bili su uzrokovani blokovskim sporovima oko regulisanja dva važna pitanja: slobodnog kretanja ljudi i ideja i konkretizacije vojnih aspekata bezbednosti Evrope (odnosno mera koje bi vodile jačanju uzajamnog poverenja). U oba slučaja do kompromisa se došlo zahvaljujući posredovanju grupe neutralnih i nesvrstanih evropskih zemalja, koje počinju da sve organizovanije i sve efikasnije preuzimaju misiju medijatora između dveju suprotstavljenih strana.

Kada je reč o slobodnom kretanju ljudi i ideja, poseban problem je bio u tome što blokovi nisu pokazivali dovoljno spremnosti da odstupe od svojih ekstremnih polaznih stavova u čemu su naročito prednjačili SSSR i njegovi saveznici. Oni su insistirali na izrazito restriktivnoj primeni odredbi u vezi sa ovom tačkom dnevnog reda (koja bi značila konzerviranje postojećeg stanja), dok je Zapad zahtevao neograničenu primenu (iako je bio svestan da bi takvo rešenje vodilo snažnom urušavanju totalitarnih režima na Istoku, što, naravno, Sovjeti ne bi mogli prihvatili ni po koju cenu). ${ }^{42}$ Neslaganje između Istoka i Zapada koje je rezultiralo višemesečnom blokadom rada Konferencije, prebrođeno je uz pomoć i posredstvom osam neutralnih i nesvrstanih zemalja (Austrije, Švajcarske, Švedske, Finske, Lihtenštajna, Malte, Kipra i Jugoslavije). Ove države su predložile izbalansiran i realan aranžman, prihvatljiv za obe strane. Naime „zaštitne odredbe“, na kojima je insistirao blok prosovjetskih država, uključene su u prvi princip Deklaracije o principima odnosa država-učesnica - $u$ princip o suverenoj jednakosti i eksplicitno unete u preambulu „treće korpe“. Načelne odredbe o doslednom sprovođenju u život ljudskih sloboda i osnovnih prava, na kojima je insistirao Zapad (u cilju konkretizovanja obaveza istočnoevropskih zemalja

${ }^{41}$ DA MSP, PA, Jugoslavija, 1974, fasc. 177, sign. 436559, Informacija o dosadašnjem toku II faze Konferencije o evropskoj bezbednosti i saradnji, Ženeva, 18. septembar 1973-26. jul 1974; Isto, sign. 462567, Informacija delegacije o sadašnjem toku II faze Konferencije o evropskoj bezbednosti i saradnji; AJ, KPR, I-3-a/107-212, Informacija o dosadašnjem toku II faze KEBS.

${ }^{42}$ Isto, sign. 453360, Informacija o dosadašnjem radu i karakteristikama II faze KEBS; Isto, sign. 436559, Informacija o dosadašnjem toku II faze Konferencije o evropskoj bezbednosti i saradnji, Ženeva, 18. septembar 1973-26. jul 1974. 
u pogledu slobode kretanja ljudi i ideja) - unete su takođe u Preambulu i uključene u deseti princip Deklaracije - o savesnom ispunjavanju međunarodnih obaveza država-učesnica Konferencije. ${ }^{43}$

Drugi problem koji je takođe doveo do ozbiljne blokade rada Konferencije, a ticao se vojnih aspekata bezbednosti, odnosno mera koje bi vodile jačanju uzajamnog poverenja, uzrokovan je neslaganjem blokovskih država oko osnovnog pitanja koje je tu razmatrano - notifikacije većih vojnih manevara. Iako su članice Varšavskog pakta načelno podržavale ideju o poželjnosti uzajamnog obaveštavanja evropskih država o planiranim vojnim manevrima - u praksi se pokazalo da im ta ideja nije bila nimalo bliska i da su spremne na sve kako bi se njen domašaj sveo na minimum i na uopštene neobavezne formulacije (sovjetska ideja o „dobrovoljnoj osnovi notifikacije manevara"). Članice NATO-a su, pak, forsirale maksimalističke zahteve, koji nisu imali nikakvog dodira sa realnošću, već su isključivo imali karakter propagandne kampanje kojom bi se što više kompromitovala spoljna politika SSSR-a. ${ }^{44}$

Spor između blokova se najdrastičnije ispoljio u sklopu rasprave o ključnim elementima notifikacije vojnih manevara - roku obaveštavanja o manevrima, veličini manevara i dubini zone manevara. Zapadne zemlje su insistirale da rok obaveštavanja o manevrima bude 60 dana, dok su istočnoevropske predlagale da rok bude samo 5 dana. Predlog Zapada o minimalnoj veličini vojnih formacija čiji se manevri moraju prijaviti bio je 12.000 vojnika (što je značilo da se praktično svi manevri moraju prijavljivati), dok su Sovjeti insistirali da se prijavljuju samo manevri u kojima učestvuju snage jačine bar jednog korpusa (40.000 vojnika). Što se, pak, zone manevara tiče - Zapad je smatrao da se moraju prijavljivati svi vojni manevri na evropskom prostoru, bez obzira na to koliko su udaljeni od granice suseda, dok su zemlje Varšavskog pakta insistirale da se prijavljuju samo manevri u užoj graničnoj oblasti. ${ }^{45}$

Taktiziranje dveju strana i njihovo oklevanje da prve učine neki korak u pravcu prihvatljivog kompromisa, nagoveštavali su novu blokadu u radu Konferencije. Pa, ipak, ta blokada je posle višemesečnog zastoja na kraju otklonjena. Pritisak vremena učinio je svoje. Obe grupacije su nesumnjivo bile zainteresovane za uspešno okončanje pregovora i kodifikaciju dela svojih zahteva u sklopu Završnog dokumenta. Elementi kompromisnog rešenja nalazili su se u revidiranom jugoslovenskom predlogu voj-

${ }^{43}$ Konferencija o evropskoj bezbednosti i saradnji, Dokumenti KEBS: 1975-1995, $10-16$.

${ }^{44}$ DA MSP, PA, Jugoslavija, 1974, fasc. 177, sign. 436559, Vojni aspekti bezbednosti; AJ, KPR, I-2/63, Izveštaj o Konferenciji o evropskoj bezbednosti i saradnji.

${ }^{45}$ Godišnjak Instituta za međunarodnu politiku i privredu. 1974, 88-90; Godišnjak Instituta za međunarodnu politiku i privredu. 1975, 74-79. 
nih mera, ${ }^{46}$ koji je podnela grupa od šest neutralnih i nesvrstanih zemalja (Švedska, Finska, Švajcarska, Austrija, Kipar, Jugoslavija), uz snažnu podršku Rumunije. Taj predlog obuhvatao je "mere jačanja poverenja“ - prethodnu notifikaciju većih vojnih manevara i pokreta trupa u Evropi, pozivanje stranih posmatrača na te manevre, uzajamno obaveštavanje susednih zemalja o manjim manevrima, uzdržavanje od svih vidova vojnih aktivnosti koje izazivaju uzajamno nepoverenje i tenzije i objavljivanje opštih podataka o vojnim budžetima. ${ }^{47}$ Drugi deo predloga odnosio se na principe kojima države-učesnice Konferencije treba da se rukovode u pregovorima o smanjenju oružanih snaga i naoružanja. ${ }^{48}$ Radilo se zapravo o principima za čiju kodifikaciju se Jugoslavija zalagala tokom cele Konferencije, uprkos snažnom otporu blokovskih država. Smisao ove jugoslovenske akcije bio je $\mathrm{u}$ tome da se $\mathrm{u}$ vojne pregovore uključe i zemlje-učesnice KEBS-a i da se ograniči dotadašnji ekskluzivni monopol dve supersile, da same ili u užem krugu svojih blokovskih saveznika, u strogoj tajnosti, vode pregovore o svim ključnim vojnim pitanjima i razoružanju. ${ }^{49}$

Zahvaljujući sve ofanzivnijem nastupu grupe neutralnih i nesvrstanih zemalja na Konferenciji o evropskoj bezbednosti i saradnji, tokom druge faze pregovora $\mathrm{u}$ Ženevi uključeno je u Završni dokument posebno poglavlje, posvećeno pitanjima bezbednosti i saradnje na području Mediterana. Samim tim proširen je i dnevni red Konferencije na još jednu temu („peta korpa“), na čemu je od samog početka insistirala Jugoslavija. To je bilo u duhu jugoslovenske teze o „nedeljivosti mira“, koju je često u javnim

${ }^{46} \mathrm{U}$ prvobitnoj verziji svog predloga (lišenog bilo kakvih cifarskih parametara), Jugoslavija je insistirala na postizanju sporazuma o ograničavanju nekih vidova vojnih aktivnosti u Evropi i na otpočinjanju pregovora o smanjenju naoružanja i vojnih efektiva. Pod tim se podrazumevalo: ograničavanje vojnih manevara u politički i strateški osetljivim regionima Evrope, zabrana upotrebe međunarodnih voda i međunarodnog vazdušnog prostora za demonstraciju oružane sile na granicama suverenih država, uzdržavanje od upotrebe vojne sile, sporazumno zaustavljanje eskalacije vojnog prisustva na tlu Evrope. Ti stavovi su formulisani još 1970. godine i dosledno propagirani tokom prve faze Konferencije o evropskoj bezbednosti i saradnji. AJ, KPR, I-2/63, Nacrt platforme SFRJ za Konferenciju o evropskoj saradnji i bezbednosti, 8. jun 1973.

${ }^{47}$ DA MSP, PA, Jugoslavija, 1974, fasc. 176, sign. 417633, Informacija delegacije SFRJ o radu II faze KEBS-a.

${ }^{48}$ To su bili sledeći principi: međuzavisnost političkih i vojnih vidova bezbednosti $u$ Evropi, nedeljivosti pojedinačne i opšte evropske bezbednosti, poštovanje interesa bezbednosti trećih (onih koji ne učestvuju u pregovorima) i obaveštavanje svih evropskih država o toku i rezultatima pregovora. Konferencija o evropskoj bezbednosti i saradnji, Dokumenti KEBS: 1975-1995, 22.

${ }^{49}$ Neuspeh u okviru druge faze pregovora o strateškom naoružanju SAD i SSSR SALT II („Strategic Arms Limitation Talks“), vođenih upravo u vreme održavanja KEBS-a, jugoslovenski zvaničnici su videli u tome što su iz tih pregovora potpuno isključene ostale države. AJ, KPR, I-2/63, Vojni aspekti evropske bezbednosti. 
nastupima isticao Tito, ukazujući na to da se krizna žarišta sa Mediterana i Bliskog istoka, kao i sa celog afro-azijskog prostora, u najkraćem roku mogu proširiti i na Evropu, „da Evropa ne može biti ostrvo spokoja i blagostanja u moru svjetske nestabilnosti“ i da „rješenja za vitalna pitanja svoje bezbednosti i prosperiteta, Evropa ne može tražiti zatvaranjem u sebe, jer bi to neizbježno vodilo njenoj političkoj i ekonomskoj degradaciji“ “ ${ }^{50}$ Jugoslovenski predstavnici su insistirali na tome da pravila iz Deklaracije o principima odnosa između zemalja-učesnica Konferencije moraju da važe i u odnosima tih država sa mediteranskim zemljama neučesnicama tog skupa. Ovakvi jugoslovenski stavovi tokom Konferencije o evropskoj bezbednosti i saradnji naišli su na snažnu podršku dve nesvrstane evropske države: Kipra i Malte, a kasnije i svih neutralnih evropskih država. ${ }^{51} \mathrm{U}$ duhu integralnog tretiranja evropske i mediteranske bezbednosti učinjen je i svojevrstan presedan u radu Konferencije. Naime, u izradi posebnog poglavlja u Završnom aktu, posvećenog Mediteranu, učestvovalo je i pet mediteranskih, neevropskih država: Egipat, Sirija, Maroko, Tunis i Alžir. ${ }^{52}$

Nastojeći da tokom Konferencije o evropskoj bezbednosti i saradnji promovišu premise i načela politike nesvrstanosti, članovi jugoslovenske delegacije su bili nosioci čitavog niza inicijativa usmerenih na usvajanje određenih formulacija $u$ Završnom dokumentu u kojima bi se povezivalo pitanje evropske bezbednosti sa „uklanjanjem blokovske podele sveta“. S druge strane, Jugoslavija je na sve načine pokušavala da evropski pregovarački proces oslobodi regionalne dimenzije i dâ mu širi, univerzalni karakter. Takva strategija proizilazila je i iz odluka i dokumenata usvojenih na Samitu nesvrstanih u Alžiru, održanom upravo u vreme kada se održavala i Konferencija o evropskoj bezbednosti i saradnji (septembra 1973). O intenciji ovakvog nastupa jugoslovenske delegacije, ministar inostranih poslova Miloš Minić detaljno je izveštavao svoje saradnike na sednicama Predsedništva SFRJ i sastancima najužeg partijskog rukovodstva. Okosnica je bila u vezi između KEBS-a i Samita u Alžiru, u nastojanju jugoslovenskih delegata da istaknu „da mi imamo jednu jedinstvenu nesvrstanu politiku; da je naša evropska politika sastavni deo ove jedinstvene nesvrstane spoljne politike; da naši stavovi u Helsinkiju moraju biti zasnovani na istoj osnovi, kao naši

${ }^{50}$ AJ, KPR, I-2/63, Govor predsednika. Tita na Konferenciji o evropskoj bezbednosti i saradnji u Helsinkiju.

${ }^{51}$ DA MSP, PA, Jugoslavija, 1974, fasc. 177, sign. 436559, Vojni aspekti bezbednosti; AJ, KPR, I-2/63, Izveštaj o Konferenciji o evropskoj bezbednosti i saradnji.

${ }^{52}$ DA MSP, PA, Jugoslavija, 1974, fasc. 176, sign. 41359, Problem Mediterana (Informacija o dosadašnjem radu II faze KEBS); Isto, sign. 462567, Mediteranski aspekt evropske bezbednosti i saradnje; AJ, KPR, I-2/63, Pitanja koja se tiču bezbednosti i saradnje u Sredozemlju. 
stavovi u Alžiru; da mi nemamo jedne stavove za Helsinki a druge stavove za Alžir". ${ }^{33}$

Budući da je jedna od glavnih odluka Alžirskog samita bila odluka o pokretanju međunarodne akcije u cilju radikalne transformacije sistema međunarodnih ekonomskih odnosa i ublažavanja sve većeg jaza koji je delio bogati Sever od siromašnog Juga - Jugoslavija se na KEBS-u nametnula kao glavni zagovornik ove ideje. Ohrabrivalo ju je to što je Generalna skupština UN, na Vanrednom zasedanju tokom 1974. godine (na inicijativu nesvrstanih zemalja), usvojila Deklaraciju o uspostavljanju novog međunarodnog ekonomskog poretka. Međutim, ovakva nastojanja Jugoslavije, zbog oštrog protivljenja zapadnih država, nisu urodila plodom. Sva ta rasprava, vođena u sklopu druge tačke dnevnog reda („pitanja saradnje u oblasti privrede, nauke i tehnologije i zaštite čovekove okoline"), u velikoj meri se svodila na potrebu da se obezbede uslovi za što izdašniju pomoć bogatih zapadnih država „evropskim i vanevropskim zemljama u razvoju“. Pošto na Zapadu nije baš iskazana sklonost da se preuzme uloga ovakvog izdašnog darodavca, debata je, prvo, sužena na „evropski Jug“ (na ekonomske probleme „manje razvijenih evropskih država"), a potom svedena na uopštene deklarativne formulacije koje nisu nikoga obavezivale na preduzimanje konkretnih mera u tom kontekstu. ${ }^{54}$

Iako se tokom juna 1975, konačno, privodio kraju rad na uobličavanju Završnog dokumenta Konferencije, pitanja vezana za četvrtu tačku dnevnog reda - kontinuitet konferencije, ostala su jedina sfera u kojoj se nije prešlo na redakcioni rad. Članice NATO-a su do kraja druge faze Konferencije zadržale krajnje rezervisan stav o ovom pitanju, suprotstavljajući se svakom rešenju koje bi impliciralo institucionalizaciju, odnosno organizovano nastavljanje pregovaračkog procesa iniciranog na Konferenciji o evropskoj bezbednosti i saradnji. Zemlje Varšavskog pakta, sa izuzetkom Rumunije, imale su sličan stav, mada su dozvoljavale mogućnost sazivanja novih sveevropskih skupova. ${ }^{55}$

Jedine stvarne pristalice nastavljanja pregovaračkog procesa o bezbednosti Evrope i posle okončanja KEBS-a bile su, zapravo, neutralne i nesvrstane države i Rumunija. Njihovo polazište po pitanju kontinuiteta

${ }^{53}$ AJ, Predsedništvo SFRJ, 803-17, Izlaganje saveznog sekretara za inostrane poslove, Miloša Minića, Magnetofonski snimak XXI sednice Predsedništva SFRJ, održane 25. juna 1973.

${ }^{54}$ DA MSP, PA, Jugoslavija, 1974, fasc. 177, sign. 436559, Jugoslovenske inicijative na KEBS-u; Isto, sign. 462567, Ekonomska saradnja (druga tačka dnevnog reda); AJ, KPR, I2/63, Ekonomska saradnja.

${ }^{55}$ DA MSP, PA, Jugoslavija, 1974, fasc. 177, sign. 462567, Kontinuitet; DA MSP, PA, 1974, fasc. 176, sign. 417633, Informacija delegacije SFRJ o radu II faze KEBS-a; AJ, KPR, I-2/63, Izveštaj o Konferenciji o bezbednosti i saradnji, 13. oktobar 1975. 
uglavnom je proizilazilo iz jugoslovenskog predloga, formulisanog marta 1974. tokom druge faze Konferencije. Suština tog predloga sastojala se $u$ zahtevu za uspostavljanje stalnog, opšteevropskog tela (Stalnog saveta), koje bi koordinisalo i iniciralo aktivnosti evropskih država u pravcu primene i realizacije odluka usvojenih na Konferenciji. Vanblokovske zemlje su ispoljavale bojazan da bi u slučaju izostanka odluke o očuvanju kontinuiteta Konferencije - došlo do gašenje započetog pregovaračkog procesa evropskih država i da bi se proces detanta u Evropi ponovo sveo samo na pregovore i sporazume blokova. Neutralne i nesvrstane zemlje su se nesumnjivo osećale mnogo sigurnije i bezbednije dok su sve evropske države, plus SAD i Kanada, sedele zajedno za pregovaračkim stolom. Stoga je za njih adekvatno rešavanje ove četvrte tačke dnevnog reda imalo prvorazredan značaj. ${ }^{56}$

Međutim, zbog snažnog otpora blokovskih sila, ideja o kontinuitetu je samo delimično prihvaćena i formulisana na uopšten način u Završnom dokumentu. Pa ipak, ostavljena je mogućnost da se posle Konferencije o evropskoj bezbednosti i saradnji održavaju periodični sastanci predstavnika ministarstava inostranih poslova zemalja-učesnica, s tim što je odluka o konačnom rešenju pitanja kontinuiteta odložena za prvi sastanak te vrste $u$ Beogradu, sredinom 1977. godine. Usvojen je stav da se sledeći sastanak KEBS-a u Beogradu održi najpre na nivou eksperata, a potom predstavnika ministara inostranih poslova. ${ }^{57}$

\section{Treća faza - zatvaranje Konferencije}

Pošto je u noći 20/21. jula 1975. „skinuto“ sa dnevnog reda i pitanje kontinuiteta, konačno je završena neočekivano duga druga faza KEBS-a. Naredna faza trajala je samo tri dana. Održana je od 30. jula do 1. avgusta 1975 u Helsinkiju, u palati „Finlandija“. Imala je uglavnom svečani karakter i svodila se na formalno usvajanje donetih odluka i potpisivanje završnih dokumenata od strane šefova država-učesnica skupa. ${ }^{58}$ Otvorio ju je predsednik zemlje domaćina, Urho Kekonen, u prisustvu najviših predstavnika evropskih zemalja, SAD i Kanade. „Evropa stupa u novu eru“ - izjavio je finski predsednik i dodao: „Ova je konferencija jedinstvena i neuporediva s bilo čime prethodnim u istoriji Evrope“. ${ }^{59}$ Konferencije.

${ }^{56}$ AJ, KPR, I-2/63, Izveštaj o Konferenciji o bezbednosti i saradnji, Kontinuitet

${ }^{57}$ DA MSP, PA, Jugoslavija, 1975, fasc. 181, sign. 437435, Kontinuitet i dalji zadaci; Konferencija o evropskoj bezbednosti i saradnji, Dokumenti KEBS: 1975-1995, 69-70.

${ }_{58}$ AJ, KPR, I-2/63, Treća faza KEBS-a; Zabeleške o pripremama za treću fazu Konferencije o evropskoj bezbednosti i saradnji; DA MSP, PA, Jugoslavija, 1975, fasc. 181, sign. 437435, Informacija o III fazi KEBS-a, održanoj u Helsinkiju od 30. jula do 1. avgusta 1975.

59 „Govor predsednika Finske Urha Kekonena na Konferenciji o evropskoj bezbednosti i saradnji u Helsinkiju“, Borba, 31. 7. 1975. 
Svi lideri zemalja učesnica Konferencije jednodušno su podržali konstataciju finskog predsednika. Novi američki predsednik Džerald Ford (Gerald Ford), čiji je govor očigledno velikim delom bio namenjen američkom javnom mnjenju, u svom istupanju obrnuo je redosled delova Završnog akta. Prvo je govorio o „slobodnijem kretanju ljudi i ideja“, zatim o unapređenju privredne saradnje među evropskim zemljama, a tek na kraju o principima odnosa između država-učesnica. Šef sovjetskih komunista Leonid Brežnjev ocenio je kao najvažniju tekovinu Konferencije „izvlačenje potrebnog političkog bilansa Drugog svetskog rata“, a poljski lider Edvard Gjerek (Edward Gierek) i šef istočnonemačke delegacije Erih Honeker (Erich Honecker) precizirali su, u neku ruku, intenciju ove Brežnjevljeve poruke. Prvi je, govoreći o značaju KEBS-a, akcenat stavio na obezbeđivanje „političko-teritorijalnog status kvoa u Evropi“, a drugi, na garancije u pogledu „nepovredivosti granica u Evropi“ ${ }^{60}$

Josip Broz Tito je u svom govoru, pak, akcenat stavio na odrednice Konferencije koje je Jugoslavija posebno forsirala u Helsinkiju. Okarakterisao je Konferenciju kao „demokratski dijalog ravnopravnih učesnika, i velikih i malih" i izrazio uverenje da će ovaj skup ostati zabeležen u istoriji kao „prekretnica u okretanju Evrope ka koegzistenciji i miru“, ali i kao skup „od značaja ne samo za Evropu, nego i za cijeli svijet“. Konferencija „ne sme da predstavlja kraj, već samo početak jednog procesa“, istakao je Tito. ${ }^{61}$

Osnovnu slabost Završnog akta iz Helsinkija, Tito i njegovi saradnici, pak, videli su u činjenici da je on, s obzirom da je predstavljao kompromis tri globalna politička prilaza (Istoka, Zapada i Trećeg sveta), bio suviše uopšten, široko formulisan, neprecizan, nejasan i zasnovan na polovičnim rešenjima. To se donekle činilo razumljivim, jer je složena materija, koja je razmatrana, zahtevala da se prvo postigne generalni sporazum u načelu, pa da se tek onda pređe na njegovu konkretizaciju. Stoga su velike nade polagane u sledeći sastanak u Beogradu 1977. godine, na kome bi se moglo oče-

60 „Govor predsednika SAD Džeralda Forda“, Borba, 2. 8. 1975; „Govor Generalnog sekretara KPSS Leonida Brežnjeva“, Borba, 1. 8. 1975; „Govor Prvog sekretara Poljske ujedinjene radničke partije Edvarda Gjereka“, Borba, 1. 8. 1975; „Govor generalnog sekretara Partije socijalističkog jedinstva Nemačke Eriha Honekera“, Borba, 31. 7. 1975. Sovjeti su smatrali da Završni akt iz Helsinkija predstavlja potvrdu postojećih evropskih granica, a KEBS svojevrsnu super-Jaltu, kojom je Zapad međunarodno priznao legitimitet postojećeg sistema odnosa u Evropi. U tom smislu, zvaničnici iz Moskve su procenjivali da je time potvrđeno sovjetsko pravo da istočnoevropske zemlje trajno ostanu pod sovjetskom sferom uticaja. Ovakav stav Brežnjev je otvoreno izneo tokom susreta sa američkim predsednikom Fordom, posle završetka KEBS-a, u Helsinkiju, 1976. L. Čehulić Vukadinović, n. d., 86.

${ }^{61}$ AJ, KPR, I-2/63, Govor predsednika Tita na Konferenciji o evropskoj bezbednosti i saradnji u Helsinkiju. 
kivati konkretno tretiranje svake posebne grupe pitanja koja su okvirno regulisana Završnim aktom iz Helsinkija. ${ }^{62}$

Gledano iz današnje perspektive, nade jugoslovenskih zvaničnika, pa i ostalih evropskih nesvrstanih ili neutralnih država u pogledu svrsishodnosti i efikasnosti kontinuiranog i organizovanog nastupa učesnica KEBSa - nisu se ostvarile i nisu se pokazale realnim. U tom smislu, Beogradska konferencija 1977. imala je isključivo manifestacioni karakter i nije suštinski doprinela rešavanju nijednog značajnijeg pitanju koje je bilo na dnevnom redu. Sličan je bio ishod i narednih konferencija o evropskoj bezbednosti i saradnji: u Madridu (1980-1983) i Beču (1986-1989). Ovaj svojevrsni debatni klub prerastao je od 1. januara 1995. u međunarodnu organizaciju - OEBS, na osnovu odluke donete na četvrtom samitu evropskih država, održanom u Budimpešti, od 5. do 6. decembra 1994. Tako smo sada svedoci svojevrsnog paralelizma dve slične međunarodne organizacije - OUN i OEBS, čiji odnos nije pravno regulisan. Često se može čuti mišljenje da taj paralelizam krnji ugled i sužava manevarski prostor Ujedinjenim nacijama u uslovima kada se javlja „novi Istok“, „novi Zapad“ i „novi Hladni rat", a kada više nema umirujuće diplomatije neutralnih i nesvrstanih zemalja.

\section{IZVORI I LITERATURA}

- Arhiv Jugoslavije (AJ), fondovi: Centralni komitet Saveza komunista Jugoslavije (CK SKJ), 507; Predsedništvo SFRJ, 803; Kabinet Predsednika Republike (KPR) 837.

- Diplomatski arhiv Ministarstva spoljnih poslova Republike Srbije (DAMSP), Politička arhiva (PA), Jugoslavija, 1972-1975.

- Borba, Beograd

- Spoljnopolitička dokumentacija, Beograd

- Aćimović, Ljubivoje. Problemi bezbednosti u Evropi. Beograd: IMPP/Prosveta, 1978.

- Aćimović Ljubivoje, i Sonja Dapčević-Oreščanin. Materijali o evropskoj bezbednosti i saradnji. Beograd: IMPP, 1969.

${ }^{62}$ Lj. Aćimović, n. d., 344-345, 354-358; DA MSP, PA, Jugoslavija, 1976, fasc. 184, sign. 450704, Neka aktuelna pitanja o sprovođenju u život Završnog dokumenta Helsinške konferencije i Beogradski sastanak KEBS-a; Isto, fasc. 183, sign. 42574, Cirkularni telegram svim jugoslovenskim ambasadama u zemljama-učesnicama KEBS-a, 2. februar 1976; Isto, fasc. 184, sign. 435307, Beogradski sastanak KEBS-a i neka aktuelna pitanja razvoja u Evropi posle Helsinkija; Isto, fasc. 183, sign. 41800, Ostvarivanje zaključaka Konferencije o evropskoj bezbednosti i saradnji i naša aktivnost na tom planu, 22. januar 1976. 
- Bogetić, Dragan. Jugoslovensko-američki odnosi 1961-1971. Beograd: ISI, 2012.

- Bogetić, Dragan. Nova strategija spoljne politike Jugoslavije 1956-1961. Beograd: ISI, 2006.

- Bogetić, Dragan. „Jugoslavija između Istoka i Zapada“. U: Jugoslavija u Hladnom ratu, Zbornik radova. Urednik Aleksandar Životić, 13-36. Beograd: INIS, 2010.

- Bogetić, Dragan. „Američke analize budućnosti Jugoslavije posle Tita s početka 70-tih godina“. Tokovi istorije, br. 1, (2012), 159-174.

- Bogetić, Dragan. „Tršćanska kriza 1974. i pogoršanje jugoslovenskoameričkih odnosa“. Istorija 20. veka, br. 1, (2015), 95-110.

- Čehulić Vukadinović, Lidija. Euroatlantizam i suvremeni međunarodni odnosi. Zagreb: Politička kultura, 2010.

- Dimić, Ljubodrag. Jugoslavija i Hladni rat. Ogledi o spoljnoj politici Josipa Broza Tita (1944-1974). Beograd: Arhipelag, 2014.

- Dimić, Ljubodrag. „Josip Broz Tito, Yugoslav Policy and the Formation of the Concept of European Security 1968-1975“. In: From Helsinki to Belgrade. Editors Vladimir Bilandžić, Dittmar Dahlmann, Milan Kosanović. Bonn: Bonn University Press, 2012.

- Đokić, Dragomir. „Kontrola naoružavanja u Evropi (predlozi i inicijative 1946-1969)". U: Materijali o evropskoj bezbednosti i saradnji. 177-264. Beograd: IMPP, 1969.

- Ficher, Thomas. „The N+N and the Folow-up Meeting in Belgrade 1977/78“. In: From Helsinki to Belgrade. Editors Vladimir Bilandžić, Dittmar Dahlmann, Milan Kosanović. Bonn: Bonn University Press, 2012.

- Godišnjak Instituta za međunarodnu politiku, 1973-1975. Beograd: IMPP, 1974-1976.

- Hronika međunarodnih događaja. 1969. Beograd: IMPP, 1970.

- KEBS 77. Beogradski sastanak. Priredio Boško Čolak-Antić, i dr. Beograd: Tanjug 1977.

- Konferencija o evropskoj bezbednosti i saradnji. Dokumenti KEBS: 19751995. Urednik Branislav Milinković. Beograd: Međunarodna politika, 1995.

- Maresca, J., To Helsinki: The Conference on Security and Cooperation in Europe, 1973-1975. Durham: Berghahn Books, 1985.

- Mates, Leo. Međunarodni odnosi socijalističke Jugoslavije. Beograd: Nolit, 1976.

- Nikoliš, Dušan. SAD. Strategija dominacije. Beograd: Radnička štampa, 1985.

- Petković, Ranko. Aktivnost grupe neutralnih i nesvrstanih zemalja na KEBSu. Zagreb: FPZ, 1979. 
- Urho Kekkonnen - borac za mir. Urednik Radovan Vukadinović. Zagreb: Globus, 1977.

- Visković, Ivo. „Odnosi Jugoslavije i Sjedinjenih Američkih Država“. Jugoslovenski pregled, XXXII, (1988), 23-45.

- Vukadinović, Radovan. Evropska sigurnost i suradnja. Zagreb: Globus, 1976.

- Vukasović, Vid. „Kontrola naoružanja u Evropi (predlozi i inicijative 1946-1969)“. Materijali o evropskoj bezbednosti i saradnji. 177-264. Beograd: IMPP, 1969.

- Živanov, Sava. Socijalizam i nesvrstane zemlje. Beograd, 1976.

Dragan Bogetić

\section{YUGOSLAV PARTICIPATION IN THE HELSINKI CONFERENCE ON SECURITY AND COOPERATION IN EUROPE}

1973-1975

\section{Summary}

During the Conference in Helsinki from July 1973 to August 1975, Yugoslavia, together with a group of European non-aligned and neutral countries, to a large extent contributed to freeing this conference from the antagonistic frame of block confrontations and to approaching the solution of key international problems through democratic dialogue of the participants. Yugoslav government gave great importance to the outcome of the Conference on European Security and Cooperation, because they believed that this meeting could potentially play a very important role, both within the reaffirmation of the basic premise of the policy of non-alignment, as well as the efforts to strengthen the European component of the Yugoslav foreign policy. During the meeting in Helsinki, Yugoslavia showed a special interest regarding the solution of one of the key issues on the agenda of the Conference - the questions of inviolability of borders. Namely, at this time there was a new Yugoslav-Italian dispute over the demarcation line between the two countries in the area of Trieste, established by the London Memorandum in 1954. On the other hand, in Helsinki Yugoslavia provided a favorable outcome of the debate on the necessity of linking the questions of European security with the security of the Mediterranean. This issue was due to Yugoslav initiative, included in the agenda of the Conference as a separate topic review. Given the important role of Yugoslavia at the Conference on European Security and Cooperation, the participants of this mee- 
ting agreed with the proposal that the next conference should be held in Belgrade by the middle of 1977.

KEYWORDS: blocks, neutral and nonaligned countries, United States, Soviet Union, Yugoslavia, CSCE, cooperation, borders, freedoms and human rights, negotiation, agreements

ЮГОСЛАВСКОЕ ВЫСТУПЛЕНИЕ НА СОВЕЩАНИИ ПО БЕЗОПАСНОСТИ И СОТРУДНИЧЕСТВУ В ХЕЛЬСИНКИ 1973-1975

\section{Резюме}

Во время Совещания в Хельсинки, прошедшего с июля 1973 по август 1975 г., Югославия вместе с группой неприсоединившихся и нейтральных государств значительно повлияла на то, чтобы Совещание освободилось блоковых рамках, и чтобы ключевые решения по международным проблемам принимались посредствам демократического диалога всех участников. Югославские официальные лица придавали большое значение результатам Совещания, имея в виду что оно могло потенциально сыграть очень большую роль, с одной стороны, для выхода из кризиса политики неприсоединения, с другой стороны, для максимального усиления европейской компоненты внешней политики Югославии. Особый интерес Югославия проявляла у одному из ключевых вопросов на повестке дня Совещания - неприкосновенности границ. Именно в это время возник новый югославско-итальянский спор о линии разграничения двух государств в районе Триеста, которая была утверждена Лондонским меморандумом 1954 г. С другой стороны, Югославия в Хельсинки обеспечила и положительное решение вопроса о взаимосвязи проблемы европейской безопасности и безопасности в Средиземном море. Этот задача, благодаря югославской инициативе, вошла в повестку дня Совещания, как особая тема рассмотрения. Имея в виду значительную роль Югославии на Совещании по безопасности и сотрудничеству, участники согласились с предложением, чтобы следующая конференция прошла в Белграде, в середине 1977 г.

КЛЮЧЕВЫЕ СЛОВА: блоки, нейтральные и неприсоединившиеся страны, США, СССР, Югославия, СБСЕ, сотрудничество, границы, основниые права и свободы, переговоры, соглашения 